\title{
Solar chilled drinking water sourced from thin air: modelling and simulation of a solar powered atmospheric water generator
}

\author{
Lu Aye, Biju George and Dan Wu \\ Renewable Energy and Energy Efficiency Group, Department of Infrastructure Engineering, \\ The University of Melbourne, Vic 3010, AUSTRALIA \\ Email:lua@unimelb.edu.au
}

\begin{abstract}
It is expected that there will be water scarcity in the future under the changing climate. Therefore investigations of innovative and environmentally friendly ways to produce portable water are very much essential. Atmospheric water generators (AWGs) apply vapour compression refrigeration to extract water vapour from the surrounding air. They produce drinking quality water and they require moist air and electricity. The required electricity may be produced by solar photovoltaic (PV) panels. By using solar energy the environmental impacts of an AWG associated with electricity consumption could be substantially reduced. The availability of solar energy and high humidity of air coincide with the drinking water demand. As of today the performance characteristics of stand-alone solar PV powered AWG is unknown. To address this knowledge gap a simulation model of such system has been developed. The model focuses on an individual phenomenon such as solar radiation availability, solar PV electricity output, battery storage, moisture content in the air and heat and mass transfer at the vapour compression refrigeration. The aim of this paper is to present the transient model developed and the simulation results.
\end{abstract}

Kasaragod district in the state of Kerala, India is selected as the study area. Drinking water availability is a major issue in this district during the months from February to early June. Daily climate variables like temperature, maximum and minimum relative humidity, wind speed and global solar radiation on horizontal plane and wind speed were obtained from a meteorological station located in Kasaragod.

A simulation model has been developed in TRNSYS with the following components: PV modules, Batteries, Regulator, Inverter and Atmospheric Water Generator. By using the model developed the capacity of the AWG, the number PV modules, the capacity of the battery bank required were determined for minimum daily water production of $15 \mathrm{~L}$. The water extraction efficiency of the AWG investigated varies between $5.4 \%$ and $9.3 \%$ for Kasaragod. The cooling CCOPs of the AWG investigated are between 4 and 5, which is better than conventional air-to-air heat pump. Based on the analysis it was concluded that the monthly average daily efficiency is strongly correlated to the monthly average relative humidity of the ambient air. The monthly average daily efficiency is defined as average of all the daily average efficiency for a month. The validation of the simulation model with experiments to enable practical system design optimisations, and the development of control algorithms to obtain better performance by using the validated model are recommended for the future studies.

Keywords: $\quad$ Drinking water, Solar, Atmospheric water generator 


\section{INTRODUCTION}

It is expected that there will be water scarcity in the future under the changing climate (George et al. 2011). Various ways for producing potable water have been developed. Some conventional technologies are well developed and some innovative and environmentally friendly technologies are being investigated. The concept of extracting water vapour from the surrounding air has been applied in Atmospheric water generators (AWGs). There are two popular types of AWGs: cooling condensation type and wet desiccation type. A cooling condensation type AWG applies the vapour compression refrigeration cycle and a fan which moves the filtered air over the evaporator coil. The temperature of air is lowered below its dew point and the water vapour in the air condenses (Wahlgren 2001). This type of AWGs produce drinking quality water and they require moist air and electricity. A wet desiccation type AWG uses a concentrated brine solution to absorb the water vapour in the air. The absorbed water is extracted from the solution and purified.

This study focuses on a cooling condensation type AWG which uses electricity to drive the compressor. The required electricity could be produced by solar PV panels. By using solar energy the environmental impacts of an AWG associated with electricity consumption could be substantially reduced. The schematic diagram of such system is shown in Figure 1. In general, the availability of solar energy and high humidity of air coincide with the drinking water demand. As of today the performance characteristics of solar powered AWG is unknown. To address this knowledge gap, a computer simulation model of such system has been developed. The main purpose of this paper is to present the transient model developed and the simulation results for Kasaragod.

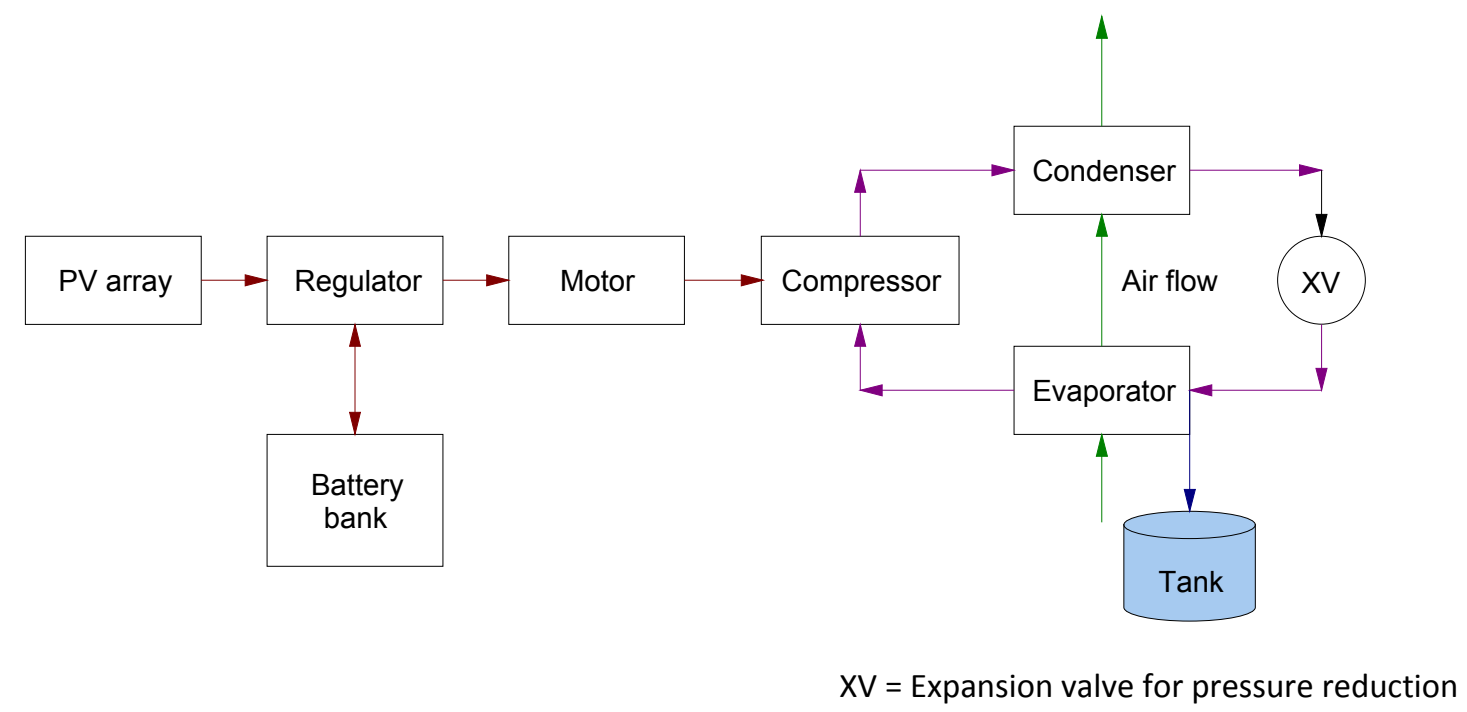

Figure 1. Schematic diagram of a PV driven AWG

Kasaragod district in the state of Kerala, India is selected as the study area. The state is blessed with two monsoons in a year and average annual rainfall is more than $3000 \mathrm{~mm}$. But this does not result in the perennial availability of water in the state. This is mainly because of the reason that the monsoon occurs in four months in a year leaving remaining 8 months dry. Drinking water availability is a major issue during the months from February to early June. Quality of water available for drinking is also a major issue during summer months. Therefore this paper focuses on the scope of producing water from Atmospheric water generators (AWGs) in producing drinking water for this region.

\section{SOLAR POWERED ATMOSPHERIC WATER GENERATOR MODEL}

The simulation model focuses on an individual phenomenon such as solar radiation availability, solar PV electricity output, moisture content in the air and heat and mass transfer at the vapour compression refrigeration. TRNSYS 16.1.3 (Klein 2006) with TESS Libraries version 2.03 was applied to develop the model and the model was used for the simulations. Figure 2 shows the TRNSYS project assembly in the Simulation Studio. The TRNSYS components libraries used are listed in Table 1. 


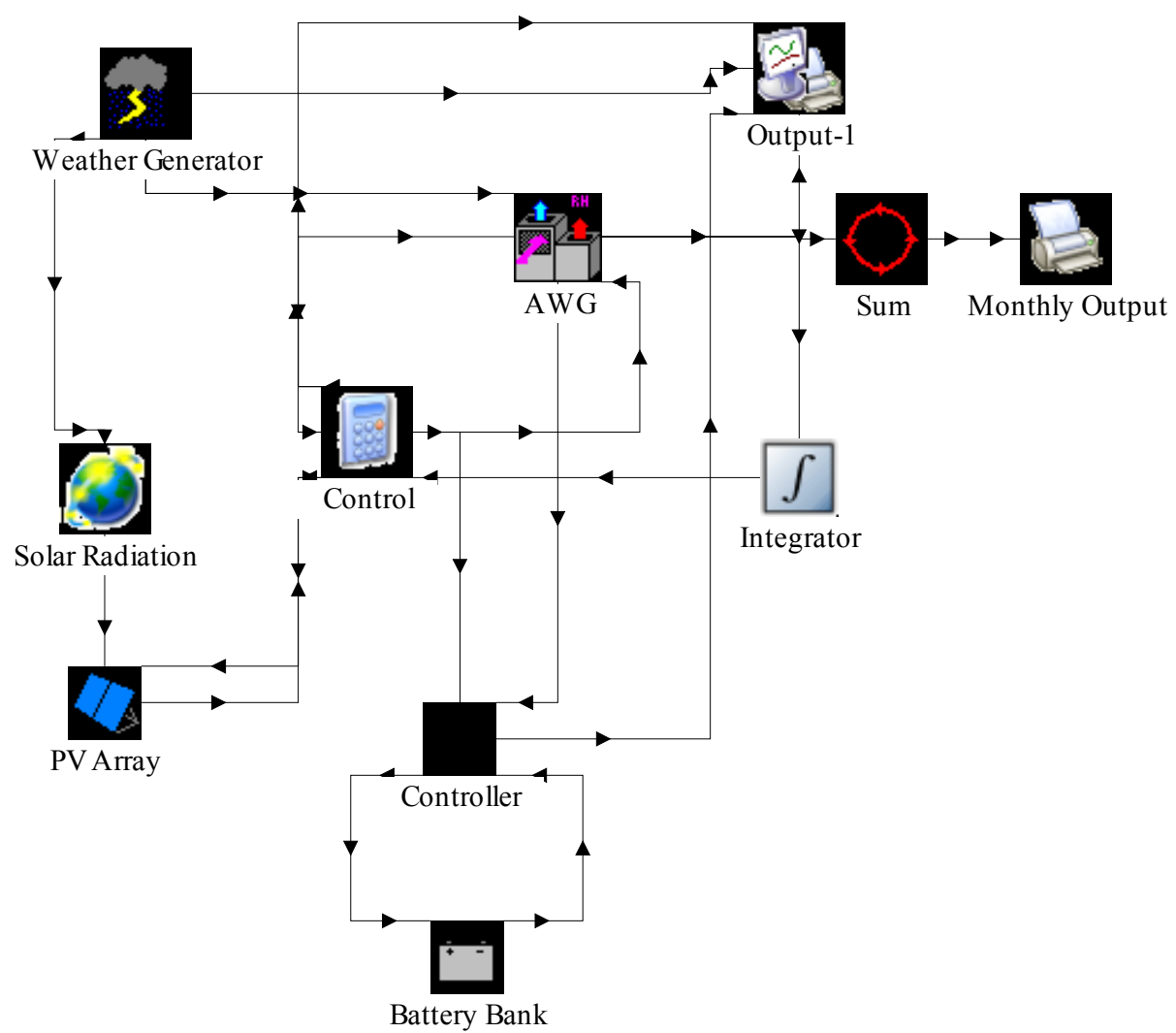

Figure 2. TRNSYS model developed

Table 1. TRNSYS components applied in the model

\begin{tabular}{|l|c|}
\hline \multicolumn{1}{|c|}{ Component } & TRNSYS Type \\
\hline Weather Generator & $54 \mathrm{c}$ \\
\hline Solar Radiation Processor & $16 \mathrm{a}$ \\
\hline Photovoltaic Panels & $94 \mathrm{a}$ \\
\hline Batteries & $47 \mathrm{a}$ \\
\hline Controller (Regulator and Inverter) & $48 \mathrm{~b}$ \\
\hline Atmospheric Water Generator (Modified Air-source Heat Pump) & $665-2$ \\
\hline Quantity Integrator & 24 \\
\hline Periodic Integrator & 55 \\
\hline Printer & $25 \mathrm{a}$ \\
\hline Online Plotter & $65 \mathrm{a}$ \\
\hline
\end{tabular}

\subsection{Study location and Climatic data}

The study area selected for this investigation is Kasaragod district in the state of Kerala, India. The latitude and longitude of the study area are $12^{\circ} 30^{\prime}, 75^{\circ} 00^{\prime}$ and has a coastline of $30 \mathrm{~km}$. The climate of the district is classified as warm humid tropical. Maximum temperature is $31.2^{\circ} \mathrm{C}$ and minimum temperature $23.6^{\circ} \mathrm{C}$. The mean annual rainfall of the district is $3462 \mathrm{~mm}$. The values of daily climate variables namely temperature, maximum and minimum relative humidity, wind speed and global solar radiation on horizontal plane and wind speed were obtained from the meteorological station located at Central Plantation Crops Research Institute, Kasaragod. Long term monthly average climatic data was extracted from the mentioned data set (Table 2). The values are comparable with the data shown in Table 3 obtained from the NASA Langley Research Center Atmospheric Science Data Center (NASA 2013). It should be noted that the wind speed at $2 \mathrm{~m}$ height is not available from NASA Atmospheric Science Data Centre. The humidity ratios were estimated by using the online Humidity Calculator provided by ROTRONIC (2013) as input required by TRNSYS Type54 (hourly weather data generator). 
Lu Aye, Biju George \& Dan Wu, Solar chilled drinking water sourced from thin air

Table 2. Kasaragod, (Latitude N 12³0', Longitude E $75^{\circ} 00^{\prime}, 19 \mathrm{~m}$ above sea level) (1980 -2007)

\begin{tabular}{|l|r|r|r|r|r|r|r|r|r|r|r|r|}
\hline \multicolumn{1}{|c|}{ Long term average } & \multicolumn{1}{c|}{ Jan } & \multicolumn{1}{c|}{ Feb } & \multicolumn{1}{c|}{ Mar } & \multicolumn{1}{c|}{ Apr } & \multicolumn{1}{c|}{ May } & Jun & Jul & Aug & Sep & Oct & Nov & Dec \\
\hline $\begin{array}{l}\text { Solar radiation } \\
\left(\mathrm{kWh} / \mathrm{m}^{2} / \text { day }\right)\end{array}$ & 4.69 & 5.11 & 5.89 & 6.00 & 6.42 & 5.17 & 4.58 & 3.61 & 4.92 & 5.83 & 5.14 & 4.75 \\
\hline Temperature $\left({ }^{\circ} \mathrm{C}\right)$ & 26.0 & 25.9 & 27.5 & 27.8 & 28.2 & 26.5 & 25.5 & 26.0 & 26.4 & 26.7 & 27.2 & 26.1 \\
\hline Relative humidity (\%) & 67.7 & 70.1 & 73.4 & 75.0 & 73.1 & 88.5 & 89.3 & 87.3 & 81.1 & 80.8 & 67.0 & 62.4 \\
\hline $\begin{array}{l}\text { Wind speed at 2 m } \\
\text { height }(\mathrm{m} / \mathrm{s})\end{array}$ & 2.7 & 3.1 & 3.6 & 3.5 & 3.7 & 4.6 & 3.7 & 2.6 & 2.0 & 2.0 & 2.0 & 2.9 \\
\hline Humidity ratio (g/kg) & 14.0 & 14.5 & 16.7 & 17.4 & 17.4 & 19.1 & 18.1 & 18.3 & 17.4 & 17.6 & 15.0 & 13.1 \\
\hline
\end{tabular}

Table 3. Data from NASA Surface meteorology and Solar Energy (1983 - 2005)

\begin{tabular}{|l|r|r|r|r|r|r|r|r|r|r|r|r|}
\hline \multicolumn{1}{|c|}{ Long term average } & \multicolumn{1}{|c|}{ Jan } & \multicolumn{1}{c|}{ Feb } & \multicolumn{1}{c|}{ Mar } & \multicolumn{1}{c|}{ Apr } & \multicolumn{1}{c|}{ May } & Jun & Jul & Aug & Sep & Oct & Nov & Dec \\
\hline $\begin{array}{l}\text { Solar radiation } \\
\left(\mathrm{kWh} / \mathrm{m}^{2} / \text { day }\right)\end{array}$ & 5.49 & 6.07 & 6.52 & 6.39 & 5.60 & 3.75 & 3.55 & 4.07 & 4.93 & 4.74 & 5.01 & 5.27 \\
\hline Temperature $\left({ }^{\circ} \mathrm{C}\right)$ & 24.9 & 25.8 & 26.9 & 26.4 & 25.8 & 24.6 & 24.0 & 23.8 & 23.9 & 24.4 & 24.9 & 24.9 \\
\hline Relative humidity $(\%)$ & 55.5 & 56.2 & 59.5 & 70.8 & 77.2 & 83.9 & 85.1 & 84.8 & 82.4 & 78.6 & 65.6 & 56.6 \\
\hline $\begin{array}{l}\text { Wind speed at } 10 \mathrm{~m} \\
\text { height }(\mathrm{m} / \mathrm{s})\end{array}$ & 3.6 & 3.0 & 3.4 & 3.4 & 4.0 & 6.0 & 5.9 & 5.6 & 4.1 & 3.1 & 3.4 & 4.3 \\
\hline
\end{tabular}

\subsection{System Component Sizes Selected}

Based on the lowest monthly water production, December was selected as the design month. For a fixed capacity of the PV module, the monthly water production depends on the solar radiation availability and the relative humidity. The deigned daily water production rate is $15 \mathrm{~L}$. The atmospheric water generator was assumed to be running between 8:00 am and 6:00 pm (10 hours). The reason is to synchronised with the solar radiation availability, which makes the required battery storage capacity smaller. The main system components required are: PV modules, Batteries, Regulator, Inverter and Atmospheric Water Generator (AWG, air-source heat pump). As shown in Figure 1 the condenser inlet air comes from the evaporator outlet air, which temperature is lower than the ambient air temperature. By running the stand alone heat pump model the average temperature drop across the evaporator is found to be about $7^{\circ} \mathrm{C}$. Therefore AWG condenser inlet air temperature is assumed to be $7^{\circ} \mathrm{C}$ lower than the dry bulb temperature of ambient air in the integrated model. The specifications of the components selected applied for the simulations are presented in Table 4.

Table 4. Component specifications

\begin{tabular}{|l|r|r|}
\hline \multicolumn{1}{|c|}{ Component } & Value & Unit \\
\hline Atmospheric Water Generator (Modified Air-source Heat Pump) & & \\
Rated cooling capacity & 3.5 & $\mathrm{~kW}$ \\
Air flow rate & 210 & $\mathrm{Ls}^{-1}$ \\
\hline Photovoltaic Modules (monocrystalline silicon) & & \\
Rated capacity & 240 & $\mathrm{~W}_{\mathrm{p}}$ \\
Area & 1.67 & $\mathrm{~m}^{2}$ \\
Module short-circuit current at reference conditions & 5.3 & $\mathrm{~A}$ \\
Module open-circuit voltage at reference conditions & 59.1 & $\mathrm{~V}$ \\
Temperature coefficient for short-circuit current & 0.03 & - \\
Temperature coefficient for open-circuit voltage & -0.33 & - \\
Nominal operating cell temperature (NOCT) & 40 & ${ }^{\circ} \mathrm{C}$ \\
Transmittance-absorptance product & 0.95 & - \\
Number of modules & 10 & - \\
\hline Batteries \& Regulator & & - \\
Cells in series & 24 & - \\
Voltage per cell & 2 & $\mathrm{~V}$ \\
Battery charging efficiency & - \\
Regulator efficiency & 0.92 & - \\
Inverter efficiency & 0.98 & - \\
Low limit on fractional state of charge & 0.95 & - \\
Cell energy capacity & 0.2 & - \\
& 24 & $\mathrm{kWh}$ \\
\hline
\end{tabular}


By using the integrated model developed the capacity of the AWG, the number PV modules, the capacity of the battery bank required were determined. The criteria for the design are meeting the daily required water and make the system stand alone (i.e. imported grid electricity to be zero).

\section{SIMULATION RESULTS AND DISCUSSIONS}

The developed model was run for hour by hour simulation for whole year. The system designed is able to operate without external electricity input to produce water. The monthly average daily water produced for each month is presented in Table 4.

The monthly average daily efficiency of the AWG was estimated from mass of water extracted and mass of air flow through and the humidity ratio by using Equation 1 for each month. It was found that the monthly average daily efficiency is strongly correlated to the monthly average relative humidity of the ambient air as expected (Figure 3).

$$
\eta_{\text {avg }}=\frac{\sum_{d=1}^{n} m_{\text {water }, d}}{\left(\sum_{d=1}^{n} m_{\text {air }, d}\right) \bar{\omega}_{\text {month }}}
$$

Where, $n=$ number of days in a month (-)

$$
\begin{aligned}
& m=\text { mass }(\mathrm{kg}) \\
& \bar{\omega}=\text { mean humidity ratio for the month }\left(\mathrm{kg}_{\text {water }} / \mathrm{kg}_{\text {air }}\right)
\end{aligned}
$$

The instantaneous compressor cooling coefficient of performance $(C C O P)$ is defined as the ratio between the cooling capacity and compressor power of the heat pump, Equation (2).

$$
C C O P=\frac{\dot{Q}_{e}}{\dot{W}_{c o m p}}
$$

Where, $\dot{Q}_{e}=$ cooling capacity $\left(\mathrm{kW}_{\mathrm{r}}\right)$

$$
\dot{W}_{\text {comp }}=\text { compressor power input }(\mathrm{kW})
$$

The simulated monthly average compressor CCOP value for each month is shown in Table 5. It should be noted that the average COP values of the AWG are better than conventional air-to-air heat pumps, because of the lower temperature of the air flowing on to the condenser of the heat pump. It should be noted that the TRNSYS model calculated hourly electricity output from the PV and battery bank for the whole year (i.e. $8760 \mathrm{hr}$ ). These energy balances were not reported in this paper, since the main focus is on the water production and the system overall performance.

Table 5. Monthly average daily water production, efficiency and compressor CCOP

\begin{tabular}{|l|r|r|r|r|r|r|r|r|r|r|r|r|}
\hline \multicolumn{1}{|c|}{$\begin{array}{c}\text { AWG performance } \\
\text { parameters }\end{array}$} & \multicolumn{1}{|c|}{ Jan } & \multicolumn{1}{c|}{ Feb } & Mar & Apr & May & Jun & Jul & Aug & Sep & Oct & Nov & Dec \\
\hline Water produced (Lpd) & 22.4 & 23.7 & 27.4 & 28.9 & 28.0 & 36.2 & 36.4 & 36.6 & 32.6 & 30.3 & 23.5 & 15.3 \\
\hline $\begin{array}{l}\text { Water extraction efficiency } \\
(\%)\end{array}$ & 7.4 & 7.6 & 7.7 & 7.8 & 7.5 & 8.8 & 9.3 & 9.3 & 8.7 & 8.0 & 7.3 & 5.4 \\
\hline Compressor CCOP (-) & 4.3 & 4.4 & 4.4 & 4.4 & 4.3 & 4.7 & 4.9 & 4.9 & 4.6 & 4.5 & 4.3 & 4.1 \\
\hline
\end{tabular}




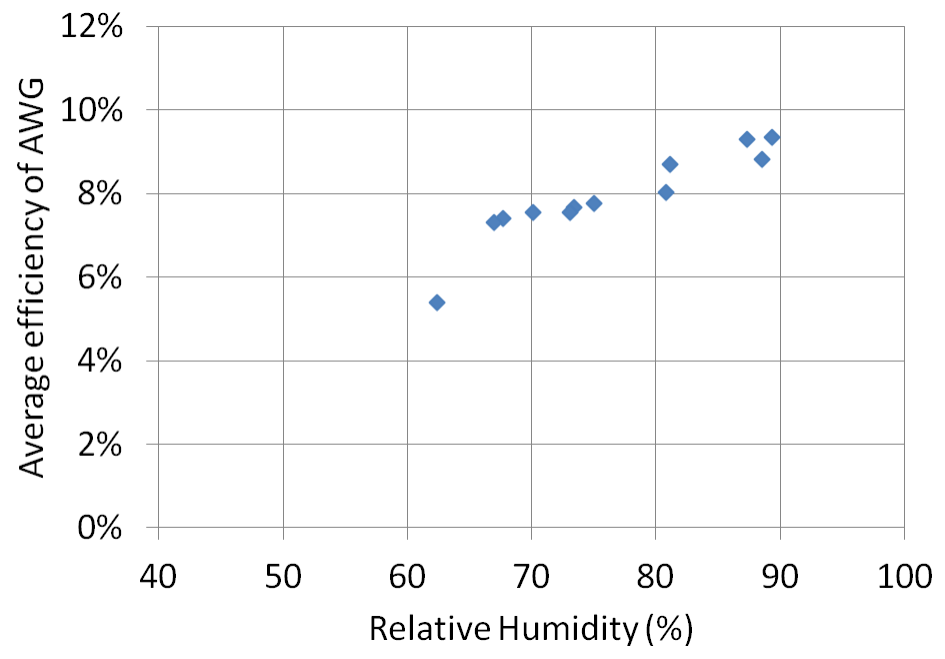

Figure 3. Monthly average water extraction efficiency vs. relative humidity

\section{CONCLUSIONS AND RECOMMENDATIONS}

The development of a simulation model for standalone Atmospheric Water Generator driven by photovoltaic modules has been presented. The general model developed can be used for design and simulation purposes. The long term average weather data, the specifications and performance parameters of the AWG, PV modules, batteries and the regulator are required as input to the model. The hourly outputs available are the amount of imported electricity, water produced, water extraction efficiency and compressor cooling coefficient of performance of the AWG. The design of AWG presented in Table 4 could produce at least 15.3 L daily. The water extraction efficiency of the AWG investigated varies between $5.4 \%$ and $9.3 \%$ for Kasaragod. The cooling CCOPS of the AWG investigated are between 4 and 5, which is better than conventional air-to-air heat pump.

The developed model should be validated with the experiments to enable practical system design optimisations. In the design of the AWG investigated, the air flow rate to the condenser of the heat pump, the air flow rate to the evaporator of the heat pump, the dry bulb temperature reduction in evaporator were assumed to be constant. These air flow rates could be controlled to obtain better performance. The validated model could be used for developing the control algorithms.

\section{ACKNOWLEDGMENTS}

The authors wish to thank Prof. Hector Malano, Infrastructure Engineering, The University of Melbourne for suggestion to develop this paper and submit it to the conference.

\section{REFERENCES}

George, B., Davidson B., Nawarathna B., Ryu D., Malano H., Kulkarni A., Patwardhan S., Deshpande N., Pavelic P., Anshuman J \& Kumar K. (2011). A modeling framework to evaluate climate change and watershed development impacts on water security. Proc 19th International Congress on Modelling and Simulation, MODSIM2011, pp. 2599-2605.

Klein, S.A., Beckman, W.A., Mitchell, J.W., Duffie, J.A., Duffie, N.A., Freeman, T.L., Mitchell, J.C., Braun, J.E., Evans, B.L., Kummer, J.P., Urban, R.E., Fiksel, A., Thornton, J.W., Blair, N.J., Williams, P.M., Bradley, D.E., McDowell, T.P., Kummert, M., Arias, D.A., Duffy M.J. (2012) TRNSYS 16: a TRaNsient SYstem Simulation program, Solar Energy Laboratory, University of Wisconsin, Madison.

NASA (see -- The National Aeronautics and Space Administration). (2013). Surface meteorology and Solar Energy A renewable energy resource web site (release 6.0), https://eosweb.larc.nasa.gov/sse/ .

ROTRONIC (2013). "Humidity Calculator” http:/www.rotronic.com/humidity_measurementfeuchtemessung-mesure_de_1_humidite/humidity-calculator-feuchterechner-mr, (accessed 4 August 2013)

Wahlgren, R.V. (2001). Atmospheric water vapour processor designs for potable water production: a review. Water Research. 35(1):1-22. 